\title{
Hubungan Tingkat Pengetahuan Tentang Dampak Rokok Terhadap Kesehatan Rongga Mulut dengan Tingkat Motivasi Berhenti Merokok pada Mahasiswa Universitas Kristen Maranatha
}

\author{
Aziizah $\mathrm{KN}^{1}$, Setiawan $\mathrm{I}^{1}$, Lelyana $\mathrm{S}^{1}$ \\ 1.Fakultas Kedokteran Gigi, Universitas Kristen Maranatha, Bandung, 40164, Indonesia \\ Email: knuuraziizah@gmail.com
}

\begin{abstract}
Abstrak
Merokok merupakan perilaku yang berdampak buruk baik terhadap kesehatan maupun lingkungan. Perilaku merokok terjadi pada berbagai kalangan sekalipun mahasiswa yang merupakan individu dengan tingkat pendidikan yang tinggi. Upaya untuk berhenti dari perilaku merokok, seorang perokok harus memiliki motivasi yang kuat, salah satu faktor yang dapat mempengaruhi motivasi seseorang adalah pengetahuan.

Tujuan penelitian ini untuk mengetahui hubungan tingkat pengetahuan tentang dampak rokok terhadap kesehatan rongga mulut dengan tingkat motivasi berhenti merokok.

Metode penelitian ini dilakukan secara analitik korelasi dengan menggunakan desain cross sectional. Semua data yang diperoleh dianalisis menggunakan uji statistik chi-square.

Hasil uji statistik pada penelitian ini menunjukkan bahwa p-value $(0,000)<0,05$, artinya terdapat hubungan antara tingkat pengetahuan dengan motivasi berhenti merokok. Hal tersebut mengindikasikan semakin tinggi tingkat pengetahuan, maka akan semakin tinggi pula motivasi berhenti merokok.

Berdasarkan hasil penelitian yang telah dilakukan dapat disimpulkan bahwa terdapat hubungan yang signifikan antara tingkat pengetahuan dampak rokok terhadap rongga mulut dengan tingkat motivasi berhenti merokok pada mahasiswa universitas kristen maranatha.
\end{abstract}

Kata kunci: pengetahuan, motivasi, merokok, rongga mulut, mahasiswa.

\section{Relationship of Knowledge Level About the Impact of Cigarettes on Oral Health with the Level of Motivation to Stop Smoking in the Students of Christian Maranatha University}

\begin{abstract}
Smoking is a bad behavior for both health and the environment. Smoking behavior occurs in various circles even though college students who are individuals with high level of education. Efforts to stop the smoking behavior, a smoker must have strong motivation, one of the factors that can affect someone's motivation is knowledge.
\end{abstract}


The purpose of this study to determine the relationship level of knowledge about the impact of smoking on oral health with the level of motivation to stop smoking.

The method of this research is analytical correlation using cross sectional design. All data obtained were analyzed using chi-square.

The results of statistical test in this study showed that p-value $(0.000)<0,05$, signify there is correlation between level of knowledge with motivation to stop smoking. This indicates the higher the level of knowledge, the higher the motivation to stop smoking.

Based on the results of research that can be concluded there is a significant relationship between the level of knowledge of the impact of cigarettes on the oral cavity with the level of motivation to stop smoking toward the students of christian maranatha university.

Keywords: knowledge, motivation, smoking, oral cavity, college students.

\section{Pendahuluan}

Merokok merupakan kebiasaan yang memiliki daya merusak cukup besar terhadap kesehatan. Menurut Organisasi Kesehatan Dunia (WHO), lingkungan asap rokok adalah penyebab berbagai penyakit, pada perokok aktif maupun pasif. Hubungan antara merokok dengan berbagai macam penyakit seperti kanker paru, penyakit kardiovaskuler, risiko terjadinya neoplasma larynx, esophagus dan sebagainya telah banyak diteliti. Namun demikian, ketergantungan terhadap rokok tidak dapat begitu saja dihilangkan.

Merokok merupakan suatu kebiasaan yang sudah tidak asing lagi di Indonesia, hasil data survei menunjukan bahwa prevalensi merokok di Indonesia terus mengalami peningkatan setiap tahunnya, baik pada laki-laki maupun perempuan. Prevalensi penduduk umur $\geq 15$ tahun yang menghisap tembakau cenderung meningkat, berdasarkan Riskesdas 2007 sebesar 34,2 persen, Riskesdas 2010 sebesar 34,7 persen dan Riskesdas 2013 menjadi 36,3 persen. Meskipun himbauan tentang bahaya merokok telah banyak disampaikan oleh berbagai pihak, namun orang-orang yang menjadi perokok tidak juga berkurang. . Lebih ironisnya orang-orang yang merokok kebanyakan adalah orang yang perekonomiannya menengah kebawah, remaja yang belum berpenghasilan tetap, bahkan kaum berpendidikan tinggi termasuk mahasiswa.

Kalangan mahasiswa dimana seharusnya mereka sudah mempunyai pengetahuan akademik yang tinggi dan lebih paham apa arti kesehatan dan lebih mengerti mengenai bahaya merokok serta sebagai generasi muda yang merupakan penerus bangsa seharusnya lebih menjaga lingkungan sekitar, namun pada kenyataannya masih banyak ditemukan mahasiswa yang mengkonsumsi rokok. Kandungan rokok membuat seseorang sulit untuk berhenti merokok karena adanya faktor adiktif pada nikotin dan faktor psikologis dimana seorang perokok akan merasakan kehilangan suatu kegiatan tertentu jika berhenti merokok. Selain faktor adiktif dalam rokok, kebiasaan merokok di kalangan mahasiswa dipicu oleh kondisi lingkungan mereka yang mayoritas adalah perokok. Berhenti merokok merupakan perubahan perilaku yang sulit dilakukan. Menurut data dari layanan berhenti merokok di Inggris menunjukkan bahwa sekitar 50\% perokok ingin berhenti merokok dalam 4 minggu, tetapi hanya $25 \%$ yang berhasil, selebihnya sekitar $75 \%$ kembali lagi merokok secara 
reguler dalam 4 - 52 minggu sejak tanggal berhenti. Begitu pula di Indonesia, hampir $50 \%$ dari perokok berencana atau berpikir untuk berhenti merokok. Namun, hanya $10 \%$ melakukan upaya untuk berhenti dalam 12 bulan terakhir.

Berhenti merokok dipengaruhi oleh motivasi. Motivasi adalah suatu proses psikologis yang mencerminkan interaksi antara sikap, kebutuhan, persepsi dan keputusan yang terjadi pada diri seseorang. Pengetahuan merupakan salah satu faktor intrinsik yang mempengaruhi terbentuknya motivasi seseorang, dengan demikian tingkat pengetahuan seseorang tentang dampak merokok sangatlah penting karena dengan pengetahuan yang dimiliki seseorang diharapkan dapat membentuk motivasi dalam hal ini adalah motivasi untuk berhenti merokok. Selain dampak rokok terhadap kesehatan secara umum mahasiswa juga perlu mengetahui dampak rokok terhadap kesehatan rongga mulut karena rongga mulut merupakan jalan masuk utama untuk makanan, minuman, dan bahan-bahan lain, seperti rokok. Larangan untuk merokok di lingkungan Univeristas Kristen Maranatha sudah diberlakukan sesuai dengan SK Rektor No 078/SK/MNJ/UKM/VIII/2017 tetapi pada kenyataannya masih terdapat sebagian mahasiswa yang merokok baik secara sembunyi-sembunyi ataupun terbuka di muka umum. Bukan hanya di lingkungan universitas tetapi juga di lingkungan fakultas. Hal ini sangat kontras dengan peraturan yang ada dan mengingat mahasiswa sebagai kaum intelektual seharusnya dapat menerapkan pola hidup yang sehat, salah satunya adalah tidak mengkonsumsi rokok sebab rokok berdampak negatif terhadap kesehatan.

Berdasarkan latar belakang, peneliti tertarik untuk melakukan penelitian bagaimana hubungan tingkat pengetahuan tentang dampak rokok terhadap kesehatan rongga mulut dengan tingkat motivasi berhenti merokok pada mahasiswa Universitas Kristen Maranatha.

\section{Metode Penelitian}

1. Jenis Penelitian

Jenis penelitian yang digunakan adalah analitik korelasi yang menganalisis hubungan tingkat pengetahuan perokok tentang dampak rokok terhadap kesehatan rongga mulut dengan motivasi berhenti merokok pada mahasiswa Universitas Kristen Maranatha.

2. Populasi dan Sampel Penelitian

Populasi yang akan diteliti adalah mahasiswa perokok di Univeristas Kristen Maranatha dengan jumlah sampel yang ditetapkan dalam penelitian ini adalah sebanyak 100 orang menggunakan formula Lemeshow untuk populasi yang tidak diketahui. Pada penelitian ini digunakan metode pengambilan sampel dengan teknik non-probability sampling dengan menggunakan proportionate purposive sampling. Purposive sampling adalah cara pengambilan sampel dengan menetapkan ciri yang sesuai dengan tujuan. 


\section{Variabel Penelitian}

Penelitian ini dibagi menjadi dua variabel, yaitu variabel terikat atau variabel dependen, variabel bebas atau variabel independen. Variabel terikat atau variabel dependen dipengaruhi oleh variabel bebas atau variabel independen.

Variabel dependen : motivasi berhenti merokok.

Variabel independen : pengetahun dampak rokok terhadap kesehatan rongga mulut.

4. Kriteria Sampel

Kriteria inklusi sampel adalah:

- Mahasiswa Universitas Kristen Maranatha yang merupakan perokok aktif.

- Bersedia menjadi subjek penelitian. Kriteria eksklusi sampel adalah:

- Mahasiswa yang berhalangan hadir pada saat pelaksanaan penelitian.

\section{Hasil}

\section{Analisis Univariat}

1. Karakteristik Responden

Tabel 1 Identitas Responden Berdasarkan Usia

\begin{tabular}{cccc}
\hline Usia & & Frekuensi & Persentase \\
\cline { 2 - 3 } 20 tahun & 20 & 20.0 \\
21 tahun & 26 & 26.0 \\
22 tahun & 33 & 33.0 \\
23 tahun & 8 & 8.0 \\
24 tahun & 9 & 9.0 \\
25 tahun & 2 & 2.0 \\
26 tahun & 2 & 2.0 \\
\hline Total & $\underline{2}$ & 100.0 \\
\hline
\end{tabular}

Tabel diatas menggambarkan identitas responden berdasarkan usia. Dari 100 responden yang diteliti, usia terendah adalah 20 tahun sedangkan usia tertinggi adalah 26 tahun. Sebagian besar responden berusia 22 tahun yaitu sebanyak 33 responden atau $33,0 \%$.

Tabel 2 Identitas Responden Berdasarkan Jenis Kelamin

\begin{tabular}{llll}
\hline Jenis Kelamin & Frekuensi & Persentase \\
\hline Laki-laki & 87 & 87.0 \\
Perempuan & 13 & 13.0 \\
\hline Total & 100 & 100.0 \\
\hline
\end{tabular}

Tabel dan diatas menggambarkan identitas responden berdasarkan jenis 
kelamin. Dari 100 responden yang diteliti, sebagian besar adalah laki-laki yaitu sebanyak 87 responden atau $87,0 \%$.

Tabel 3 Identitas Responden Berdasarkan Fakultas

\begin{tabular}{|c|c|c|}
\hline Fakultas & Frekuensi & Persentase \\
\hline Ekonomi & 31 & 31.0 \\
\hline FSRD & 10 & 10.0 \\
\hline Hukum & 5 & 5.0 \\
\hline Kedokteran Gigi & 5 & 5.0 \\
\hline Kedokteran Umum & 14 & 14.0 \\
\hline Psikologi & 12 & 12.0 \\
\hline Sastra & 5 & 5.0 \\
\hline Teknik & 12 & 12.0 \\
\hline Teknik Informatika & 6 & 6.0 \\
\hline Total & 100 & 100.0 \\
\hline
\end{tabular}

Tabel diatas menggambarkan identitas responden berdasarkan fakultas. Dari 100 responden yang diteliti, sebagian besar berasal dari fakultas Ekonomi yaitu sebanyak 31 responden atau $31,0 \%$.

Tabel 4 Identitas Responden Berdasarkan Usia Pertama Kali Merokok

\begin{tabular}{lll}
\hline Usia Pertama Kali Merokok & Frekuensi & Persentase \\
\hline 13 tahun & 7 & 7.0 \\
14 tahun & 4 & 4.0 \\
15 tahun & 20 & 20.0 \\
16 tahun & 13 & 13.0 \\
17 tahun & 24 & 24.0 \\
18 tahun & 14 & 14.0 \\
19 tahun & 11 & 11.0 \\
20 tahun & 7 & 7.0 \\
\hline Total & 100 & 100.0 \\
\hline
\end{tabular}

Tabel diatas menggambarkan identitas responden berdasarkan usia pertama kali merokok. Dari 100 responden yang diteliti, usia terendah adalah 13 tahun sedangkan usia tertinggi adalah 20 tahun. Sebagian besar responden pertama kali merokok pada usia 17 tahun yaitu sebanyak 24 responden atau $24,0 \%$.

Tabel 5 Identitas Responden Berdasarkan Mengenal Rokok Pertama Kali

\begin{tabular}{lll}
\hline Mengenal Rokok Pertama Kali & Frekuensi & Persentase \\
\hline Media cetak dan elektronik & 10 & 10.0 \\
Orangtua/keluarga & 13 & 13.0 \\
Teman & 77 & 77.0 \\
\hline Total & 100 & 100.0 \\
\hline
\end{tabular}

Tabel diatas menggambarkan identitas responden berdasarkan mengenal rokok pertama kali. Dari 100 responden yang diteliti, sebagian besar mengenal rokok 
pertama kali dari teman yaitu sebanyak 77 responden atau 77,0\%.

Tabel 6 Identitas Responden Berdasarkan Konsumsi Rokok Per Hari

\begin{tabular}{lll}
\hline Konsumsi Rokok Per Hari & Frekuensi & Persentase \\
\hline >20 batang & 5 & 5.0 \\
1 1-10 batang & 72 & 72.0 \\
$11-20$ batang & 23 & 23.0 \\
\hline Total & 100 & 100.0 \\
\hline
\end{tabular}

Tabel diatas menggambarkan identitas responden berdasarkan konsumsi rokok per hari. Dari 100 responden yang diteliti, sebagian besar merupakan perokok ringan yaitu sebanyak 72 responden atau $72,0 \%$.

Tabel 7 Identitas Responden Berdasarkan Lama Merokok

\begin{tabular}{llll}
\hline Lama Merokok & Frekuensi & Persentase \\
\hline$<5$ tahun & 46 & 46.0 \\
5-10 tahun & 52 & 52.0 \\
$>10$ tahun & 2 & 2.0 \\
\hline Total & 100 & 100.0 \\
\hline
\end{tabular}

Tabel diatas menggambarkan identitas responden berdasarkan lama merokok. Dari 100 responden yang diteliti, sebagian besar sudah merokok selama 5-10 tahun yaitu sebanyak 52 responden atau 52,0\%.

2. Gambaran Tingkat Pengetahuan Tentang Dampak Rokok Terhadap Kesehatan Rongga Mulut pada Mahasiswa Universitas Kristen Maranatha

Tabel 8 Gambaran Kesehatan Lingkungan

\begin{tabular}{ccl}
\hline Kesehatan Lingkungan & Frekuensi & Persentase \\
\hline Baik & 12 & 12.0 \\
Cukup & 82 & 82.0 \\
Kurang & 6 & 6.0 \\
\hline Total & $\underline{100}$ & $\underline{100.0}$ \\
\hline
\end{tabular}

Tabel diatas menggambarkan tingkat pengetahuan berdasarkan kesehatan lingkungan. Dari 100 responden yang diteliti, 12 responden diantaranya termasuk kategori baik, 82 responden diantaranya termasuk kategori cukup baik, dan 6 responden lainnya termasuk kategori kurang baik. Hal ini mengindikasikan bahwa sebagian besar responden termasuk kategori cukup baik dalam hal kesehatan lingkungan. 
Tabel 9 Gambaran Kesehatan Umum

\begin{tabular}{lll}
\hline Kesehatan Umum & Frekuensi & Persentase \\
\hline Baik & 7 & 7.0 \\
Cukup & 79 & 79.0 \\
Kurang & 14 & 14.0 \\
\hline Total & 100 & 100.0 \\
\hline
\end{tabular}

Tabel diatas menggambarkan tingkat pengetahuan berdasarkan kesehatan umum. Dari 100 responden yang diteliti, 7 responden diantaranya termasuk kategori baik, 79 responden diantaranya termasuk kategori cukup baik, dan 14 responden lainnya termasuk kategori kurang baik. Hal ini mengindikasikan bahwa sebagian besar responden termasuk kategori cukup baik dalam hal kesehatan umum.

Tabel 10 Gambaran Kesehatan Gigi

\begin{tabular}{lll}
\hline Kesehatan Gigi & Frekuensi & Persentase \\
\hline Baik & 16 & 16.0 \\
Cukup & 52 & 52.0 \\
Kurang & 32 & 32.0 \\
\hline Total & 100 & 100.0 \\
\hline
\end{tabular}

Tabel diatas menggambarkan tingkat pengetahuan berdasarkan kesehatan gigi. Dari 100 responden yang diteliti, 16 responden diantaranya termasuk kategori baik, 52 responden diantaranya termasuk kategori cukup baik, dan 31 responden lainnya termasuk kategori kurang baik. Hal ini mengindikasikan bahwa sebagian besar responden termasuk kategori cukup baik dalam hal kesehatan gigi.

Tabel 11 Gambaran Kesehatan Jaringan Pendukung

\begin{tabular}{lll}
\hline Kesehatan Jaringan Pendukung & Frekuensi & Persentase \\
\hline Baik & 17 & 17.0 \\
Cukup & 72 & 72.0 \\
Kurang & 11 & 11.0 \\
\hline Total & 100 & 100.0 \\
\hline
\end{tabular}

Tabel diatas menggambarkan tingkat pengetahuan berdasarkan kesehatan jaringan pendukung. Dari 100 responden yang diteliti, 17 responden diantaranya termasuk kategori baik, 72 responden diantaranya termasuk kategori cukup baik, dan 11 responden lainnya termasuk kategori kurang baik. Hal ini mengindikasikan bahwa sebagian besar responden termasuk kategori cukup baik dalam hal kesehatan jaringan pendukung. 
Tabel 12 Gambaran Kesehatan Jaringan Mukosa Mulut

\begin{tabular}{lll}
\hline Kesehatan Jaringan Mukosa Mulut & Frekuensi & Persentase \\
\hline Baik & 21 & 21.0 \\
Cukup & 62 & 62.0 \\
Kurang & 17 & 17.0 \\
\hline Total & 100 & 100.0 \\
\hline
\end{tabular}

Tabel diatas menggambarkan tingkat pengetahuan berdasarkan kesehatan jaringan mukosa mulut. Dari 100 responden yang diteliti, 21 responden diantaranya termasuk kategori baik, 62 responden diantaranya termasuk kategori cukup baik, dan 17 responden lainnya termasuk kategori kurang baik. Hal ini mengindikasikan bahwa sebagian besar responden termasuk kategori cukup baik dalam hal kesehatan jaringan mukosa mulut.

\section{Tabel 13 Gambaran Pengetahuan}

\begin{tabular}{ccc}
\hline Pengetahuan & Frekuensi & Persentase \\
\hline Baik & 31 & 31.0 \\
Cukup & 32 & 32.0 \\
Kurang & 37 & 37.0 \\
\hline Total & $\underline{100}$ & $\underline{100.0}$ \\
\hline
\end{tabular}

Tabel diatas menggambarkan tingkat pengetahuan tentang dampak rokok terhadap kesehatan rongga mulut pada mahasiswa Universitas Kristen Maranatha. Dari 100 responden yang diteliti, 31 responden diantaranya termasuk kategori baik, 32 responden diantaranya termasuk kategori cukup baik, dan 37 responden lainnya termasuk kategori kurang baik. Hal ini mengindikasikan bahwa sebagian besar responden termasuk kategori kurang baik dalam hal pengetahuan tentang dampak rokok terhadap kesehatan rongga mulut.

3. Gambaran Tingkat Motivasi Berhenti Merokok pada Mahasiswa Universitas Kristen Maranatha 
Tabel 14 Gambaran Tingkat Motivasi Berdasarkan Usia

\begin{tabular}{|c|c|c|c|c|c|c|}
\hline \multirow{2}{*}{ Usia } & & \multicolumn{3}{|c|}{ Motivasi } & & \multirow{2}{*}{ Total } \\
\hline & & Tinggi & Sedang & Rendah & & \\
\hline \multirow{2}{*}{20 Tahun } & $\mathrm{F}$ & 7 & 9 & 4 & & 20 \\
\hline & $\%$ & 35.0 & 45.0 & 20.0 & & 100.0 \\
\hline \multirow{2}{*}{21 Tahun } & $\mathrm{F}$ & 6 & 7 & 13 & & 26 \\
\hline & $\%$ & 23.1 & 26.9 & 50.0 & & 100.0 \\
\hline \multirow{2}{*}{22 Tahun } & $\mathrm{F}$ & 12 & 12 & 9 & & 33 \\
\hline & $\%$ & 36.4 & 36.4 & 27.3 & & 100.0 \\
\hline \multirow{2}{*}{23 Tahun } & $\mathrm{F}$ & 3 & 1 & 4 & 8 & \\
\hline & $\%$ & 37.5 & 12.5 & 50.0 & & 100.0 \\
\hline \multirow{2}{*}{24 Tahun } & $\mathrm{F}$ & 4 & 3 & 2 & 9 & \\
\hline & $\%$ & 44.4 & 33.3 & 22.2 & & 100.0 \\
\hline \multirow{2}{*}{25 Tahun } & $\mathrm{F}$ & 1 & 1 & 0 & 2 & \\
\hline & $\%$ & 50.0 & 50.0 & 0.0 & & 100.0 \\
\hline \multirow{2}{*}{26 Tahun } & $\mathrm{F}$ & 1 & 1 & 0 & 2 & \\
\hline & $\%$ & 50.0 & 50.0 & 0.0 & & 100.0 \\
\hline \multirow{2}{*}{ Total } & $\mathbf{F}$ & 34 & 34 & 32 & & 100 \\
\hline & $\%$ & 34.0 & 34.0 & 32.0 & & 100.0 \\
\hline
\end{tabular}

Tabel diatas menujukkan tingkat motivasi berdasarkan Usia. Dari 20 responden yang berusia 20 tahun, 7 responden diantaranya termasuk kategori tinggi, 9 responden diantaranya termasuk kategori sedang, dan 4 responden lainnya termasuk kategori rendah. Dari 26 responden yang berusia 21 tahun, 6 responden diantaranya termasuk kategori tinggi, 7 responden diantaranya termasuk kategori sedang, dan 13 responden lainnya termasuk kategori rendah. Dari 33 responden yang berusia 22 tahun, 12 responden diantaranya termasuk kategori tinggi, 12 responden diantaranya termasuk kategori sedang, dan 9 responden lainnya termasuk kategori rendah. Dari 8 responden yang berusia 23 tahun, 3 responden diantaranya termasuk kategori tinggi, 1 responden diantaranya termasuk kategori sedang dan 4 responden lainnya termasuk kategori rendah. Dari 9 responden yang berusia

24 tahun, 4 responden diantaranya termasuk kategori tinggi, 3 responden diantaranya termasuk kategori sedang, dan 2 responden lainnya termasuk kategori rendah. Dari 2 responden yang berusia 25 tahun, 1 responden diantaranya termasuk kategori tinggi, dan 1 responden lainnya termasuk kategori sedang. Dari 2 responden yang berusia 26 tahun, 1 responden diantaranya termasuk kategori tinggi, dan 1 responden lainnya termasuk kategori sedang. 
Tabel 15 Gambaran Motivasi Berdasarkan Jenis Kelamin

\begin{tabular}{|c|c|c|c|c|c|}
\hline \multirow{2}{*}{\multicolumn{2}{|c|}{ Jenis Kelamin }} & \multicolumn{3}{|c|}{ Motivasi } & \multirow{2}{*}{ Tota } \\
\hline & & Tinggi & Sedang & Renda & \\
\hline \multirow{2}{*}{ Laki-laki } & $\mathrm{F}$ & 28 & 30 & 29 & 87 \\
\hline & $\%$ & 32.2 & 34.5 & 33.3 & 100.0 \\
\hline \multirow{2}{*}{ Perempuan } & $\mathrm{F}$ & 6 & 4 & 3 & 13 \\
\hline & $\%$ & 46.2 & 30.8 & 23.1 & 100.0 \\
\hline \multirow{2}{*}{ Total } & $\mathbf{F}$ & 34 & 34 & 32 & 100 \\
\hline & $\%$ & 34.0 & 34.0 & 32.0 & 100.0 \\
\hline
\end{tabular}

Tabel diatas menunjukkan tingkat motivasi berdasarkan jenis kelamin. Dari 87 responden yang berjenis kelamin laki-laki, 28 responden diantaranya termasuk kategori tinggi, 30 responden diantaranya termasuk kategori sedang, dan 29 responden lainnya termasuk kategori rendah. Dari 13 responden yang berjenis kelamin perempuan, 6 responden diantaranya termasuk kategori tinggi, 4 responden diantaranya termasuk kategori sedang, dan 3 responden lainnya termasuk kategori rendah.

Tabel 16 Gambaran Motivasi Instrinsik

\begin{tabular}{lll}
\hline Intrinsik & Frekuensi & \% \\
\hline Tinggi & 49 & 49,0 \\
Sedang & 20 & 20,0 \\
Rendah & 31 & 31,0 \\
\hline Total & 100 & 100,0 \\
\hline
\end{tabular}

Tabel di atas menggambarkan motivasi intrinsik responden. Dari 100 orang yang diteliti, terdapat 49 orang $(49,0 \%)$ memiliki motivasi intrinsik yang tinggi, 20 orang $(20,0 \%)$ memiliki motivasi intrinsik yang sedang dan 31 orang $(31,0 \%)$ memiliki motivasi intrinsik yang rendah.

Tabel 17 Gambaran Motivasi Ekstrinsik

\begin{tabular}{lll}
\hline Ekstrinsik & Frekuensi & \% \\
\hline Tinggi & 38 & 38,0 \\
Sedang & 22 & 22,0 \\
Rendah & 40 & 40,0 \\
\hline Total & 100 & 100,0 \\
\hline
\end{tabular}


Tabel di atas menggambarkan motivasi ekstrinsik responden. Dari 100 orang yang diteliti, terdapat 38 orang $(38,0 \%)$ memiliki motivasi ekstrinsik yang tinggi, 22 orang $(22,0 \%)$ memiliki motivasi ekstrinsik yang sedang dan 40 orang $(40,0 \%)$ memiliki motivasi ekstrinsik yang rendah.

Tabel 18 Gambaran Tingkat Motivasi Berhenti Merokok

\begin{tabular}{llll}
\hline Motivasi & Frekuensi & Persentase \\
\hline Tinggi & 39 & 39.0 \\
Sedang & 24 & 24.0 \\
Rendah & 37 & 37.0 \\
\hline & Total & 100 & 100.0 \\
\hline
\end{tabular}

Tabel diatas menggambarkan tingkat motivasi berhenti merokok pada mahasiswa Universitas Kristen Maranatha. Dari 100 responden yang diteliti, 39 responden diantaranya termasuk kategori tinggi, 24 responden diantaranya termasuk kategori sedang, dan 37 responden lainnya termasuk kategori rendah. Hal ini mengindikasikan bahwa sebagian besar responden termasuk kategori tinggi dalam hal motivasi berhenti merokok.

\section{Analisis Bivariat}

Tabel 19 Hubungan antara Tingkat Pengetahuan dengan Motivasi Berhenti Merokok

\begin{tabular}{|c|c|c|c|c|c|c|}
\hline \multirow{2}{*}{\multicolumn{2}{|c|}{ Tingkat Pengetahuan }} & \multicolumn{3}{|c|}{ Motivasi } & & \multirow{2}{*}{ Total } \\
\hline & & Tinggi & Sedang & Rendah & & \\
\hline \multirow{2}{*}{ Baik } & $\mathrm{f}$ & 31 & 0 & 0 & 31 & \multirow{2}{*}{$\begin{array}{l}\chi^{2}=159.615 \\
\text { hitung }\end{array}$} \\
\hline & $\%$ & 100.0 & 0.0 & 0.0 & 100.0 & \\
\hline \multirow{2}{*}{ Cukup } & $\mathrm{f}$ & 8 & 24 & 0 & 32 & \multirow{2}{*}{$\mathrm{df}=4$} \\
\hline & $\%$ & 25.0 & 75.0 & 0.0 & 100.0 & \\
\hline \multirow{2}{*}{ Kurang } & $\mathrm{f}$ & 0 & 0 & 37 & 37 & \multirow{2}{*}{$\begin{array}{l}\chi^{2}=9.488 \\
\text { tabel }\end{array}$} \\
\hline & $\%$ & 0.0 & 0.0 & 100.0 & 100.0 & \\
\hline \multirow{2}{*}{ Total } & $\mathrm{f}$ & 39 & 24 & 37 & 100 & \multirow{2}{*}{ Sig. $=0.000$} \\
\hline & $\%$ & 39.0 & 24.0 & 37.0 & $\begin{array}{l}100 . \\
0\end{array}$ & \\
\hline
\end{tabular}

Dari tabel di atas dapat di lihat dari 31 responden yang memiliki tingkat pengetahuan baik, seluruhnya memiliki motivasi tinggi untuk berhenti merokok. Dari 32 responden yang memiliki tingkat pengetahuan cukup baik, 8 responden diantaranya memiliki motivasi tinggi untuk berhenti merokok, dan 24 responden lainnya memiliki motivasi sedang untuk berhenti 
merokok. Dari 37 responden yang memiliki tingkat pengetahuan kurang, seluruhnya memiliki motivasi rendah untuk berhenti merokok.

\section{Diskusi}

Hasil penelitian yang dilakukan pada 100 orang responden mahasiswa Universitas Kristen Maranatha menunjukkan bahwa terdapat hubungan antara tingkat pengetahuan tentang dampak rokok terhadap kesehatan rongga mulut dengan tingkat motivasi berhenti merokok. Hal tersebut dapat dilihat dari hasil analisis chi-square dengan hasil uji statistik menunjukkan bahwa p-value $(0,000)<0,05$, artinya terdapat hubungan antara tingkat pengetahuan dengan motivasi berhenti merokok. Pengetahuan merupakan dasar perubahan perilaku seorang individu, dan merupakan salah satu faktor yang berpengaruh pada motivasi seseorang untuk berhenti merokok. Semakin banyak pengetahuan perokok mengenai bahaya merokok maka keinginan untuk berhenti merokok akan semakin tinggi karena rokok mempunyai banyak dampak buruk baik untuk diri sendiri maupun orang-orang disekitar perokok, hal tersebut akan menjadi pertimbangan yang besar bagi seorang perokok untuk berhenti dari perilaku merokoknya, sedikit demi sedikit perokok akan mengurangi aktivitas merokoknya dengan dibantu faktor lainnya yang mempengaruhi motivasi untuk berhenti merokok.

Hasil penelitian ini sejalan dengan penelitian yang telah dilakukan oleh Asma, Zulkifli, dan Thaha yang berjudul Analisis Motivasi Berhenti Merokok Laki-Laki Dewasa Awal di Pesisir Puskesmas Pundata Baji. Penelitian tersebut adalah penelitian observasional analitik dengan menggunakan desain cross sectional. Populasi adalah semua laki-laki dewasa awal dan perokok yang berdomisili di pesisir wilayah kerja Puskesmas Pundata Baji Kecamatan Labakkang Kabupaten Pangkep. Berdasarkan hasil penelitian tersebut, diketahui bahwa terdapat hubungan yang signifikan antara pengetahuan dengan motivasi berhenti merokok $(\mathrm{p}=0,000)$. Hasil yang berbeda dikemukakan oleh Rahmadi, Lestari dan Yenita pada tahun 2013 yang berjudul Hubungan Pengetahuan dan Sikap Terhadap Rokok dengan Kebiasaan Merokok Siswa SMP di Kota Padang menunjukkan tidak terdapat hubungan yang bermakna antara pengetahuan dengan keinginan untuk berhenti merokok. Hal tersebut dikarenakan, keinginan dan sikap seorang perokok sangat kuat dipengaruhi oleh orang tua, teman sebaya, kepribadian, dan media informasi yang mengiklankan tentang rokok.

Perilaku merokok merupakan perilaku yang memiliki dampak buruk bagi kesehatan, tetapi pada kenyataannya masih banyak orang yang merokok bahkan orang mulai merokok ketika dia masih remaja. Data responden yang didapat dari penelitian ini bahwa dari 100 responden yang diteliti, sebagian besar responden pertama kali merokok pada usia 17 tahun yaitu sebanyak 24 responden atau 24,0\%. Masa remaja memiliki karakteristik yang membedakannya dengan periode perkembangan lainnya, antara lain masa remaja merupakan periode terjadinya banyak perubahan. Pada masa remaja peran teman sebaya sangat penting, karena pada masa ini seorang remaja lebih banyak menghabiskan waktu luang bersama temannya, sehingga jika seorang remaja dengan lingkungan teman yang banyak merokok, kemungkinan besar remaja tersebut akan mengikuti perilaku merokok, hal ini dilakukan untuk menyesuaikan diri dengan lingkungannya. Berdasarkan data responden yang didapat dari penelitian ini, bahwa 
dari 100 responden yang diteliti, sebagian besar mengenal rokok pertama kali dari teman yaitu sebanyak 77 responden atau $77 \%$.

Perilaku merokok terjadi bukan hanya pada kalangan laki-laki tetapi juga pada kalangan perempuan, walaupun jumlah perokok pada perempuan tidak sebanyak lakilaki. Hal tersebut dapat disebabkan karena adanya perbedaan pendapat masyarakat bahwa merokok di kalangan perempuan dianggap sebagai perilaku menyimpang sementara merokok di kalangan laki-laki merupakan suatu hal yang dianggap wajar sehingga perempuan akan lebih menjaga perilakunya di depan publik. Berdasarkan data responden yang didapat dari penelitian ini, dari 100 responden yang diteliti sebagian besar adalah laki-laki yaitu sebanyak 87 responden atau $87 \%$. Perilaku merokok terjadi pada berbagai golongan sekalipun mahasiswa yang mempunyai intelektual tinggi. Hal tersebut dapat disebabkan karena kebiasaan merokok yang dimulai pada usia remaja, sehingga tingkat kecanduan terhadap rokok tinggi yang berakibat sulit meninggalkan kebiasaan merokok tersebut, oleh sebab itu pihak universitas memberlakukan peraturan larangan merokok dengan membuat kawasan tanpa rokok. Walaupun tidak sepenuhya peraturan tersebut dilakukan oleh mahasiswa perokok, dengan adanya kawasan bebas rokok, mahasiswa tidak dapat merokok sembarangan di lingkungan universitas dan dengan lebih banyaknya aktivitas mahasiswa di kampus dapat membantu mengurangi frekuensi merokok pada mahasiswa. Berdasarkan data responden yang didapat dari penelitian ini, dari 100 responden yang diteliti, sebagian besar mengkonsumsi 1 sampai 10 batang rokok per hari yaitu sebanyak 72 responden atau $72,0 \%$. Kecanduan merokok membuat seorang perokok sulit untuk meninggalkan kebiasaan merokok. Semakin awal seseorang merokok makin sulit untuk berhenti merokok. Rokok mempunyai dose-response effect, artinya semakin lama waktu terpapar merokok, akan semakin besar pengaruhnya terhadap kesehatan karena toksin akan lebih banyak menumpuk pada tubuhnya. Berdasarkan data responden yang didapatkan pada penelitian ini, dari 100 respoden, sebagian besar sudah merokok selama 5-10 tahun yaitu sebanyak 52 responden atau 52,0\%. Lama merokok seseorang mempengaruhi pengalaman dan tanggapan seorang individu tentang rokok. Orang yang baru merokok atau perokok pemula sekitar $<5$ tahun, tentunya memiliki tanggapan berbeda dengan orang yang sudah merokok berat sekitar 5-10 tahun atau lebih, hal tersebut berhubungan dengan pengalaman yang dilaluinya.

Upaya mengatasi perilaku merokok yaitu seorang perokok harus mempunyai keputusan untuk mengurangi konsumsi rokok secara bertahap serta dengan niat dan motivasi yang kuat untuk tidak merokok. Tingkat pengetahuan dapat mempengaruhi seseorang termasuk juga perilaku seseorang akan pola hidup, terutama dalam memotivasi sikap dan berperan serta dalam perkembangan kesehatan. Pengetahuan yang dimiliki perokok tentang bahaya dan dampak buruk rokok terhadap kesehatannya akan menjadi pemicu untuk mengurangi tingkat ketergantungan terhadap kebiasaan merokoknya sehingga tingkat kesehatannya pun akan meningkat. Berdasarkan data responden pada penelitian ini didapatkan bahwa mahasiswa yang memiliki pengetahuan rendah tentang dampak rokok lebih banyak dibandingkan dengan mahasiswa yang memiliki pengetahuan cukup dan pengetahuan tinggi. Hal ini dapat disebabkan oleh berbagai keadaan seperti kurangnya keinginan mahasiswa untuk mencari informasi mengenai bahaya merokok dan kurangnya sosialisasi kandungan dan bahaya merokok di sekitar lingkungan mahasiswa sehingga pengetahuan mahasiswa tentang bahaya merokok akan semakin minim. 
Berbeda dengan motiviasi, berdasarkan data responden yang di dapat dari penelitian ini sebagian besar mahasiswa memiliki motivasi yang tinggi yaitu sebanyak 39\% dibandingkan dengan motivasi rendah sebanyak 37\%. Angka ini memiliki makna yang cukup baik, karena untuk dapat berhenti merokok seseorang harus memiliki motivasi yang cukup tinggi, artinya mahasiswa sudah menyadari bahwa merokok bukan perilaku yang baik karena dapat memberikan banyak dampak buruk baik terhadap kesehatan diri sendiri maupun orang disekitar lingkungan perokok. Pada kenyataannya, masih banyak mahasiswa yang merokok, hal tersebut dapat disebabkan karena lingkungan disekitar mahasiswa yang masih mendukung perilaku merokok serta kurangnya sosialisasi mengenai bahaya merokok dan cara untuk berhenti merokok. Terdapat dua faktor yang dapat mempengaruhi motivasi seseorang yaitu faktor intrinsik dan ekstrinsik. Motivasi instrinsik meliputi pengetahuan, usia, jenis kelamin, nilai dan persepsi. Motivasi ekstrinsik meliputi pengaruh orang tua, pengaruh teman, dan pengaruh iklan atau media. Faktor usia yaitu semakin bertambahnya usia seseorang maka motivasinya akan semakin meningkat dalam hal apapun dalam hidupnya, berdasarkan hasil data responden yang didapat dari penelitian ini motivasi berhenti merokok cenderung meningkat dari responden yang berusia 20 tahun sampai 26 tahun. Faktor jenis kelamin antara pria dan wanita mempunyai perbedaan, hal ini dimungkinkan karena faktor hormonal, struktur fisik, maupun norma pembagian tugas, oleh sebab itu kalangan perempuan cenderung memiliki motivasi berhenti merokok yang lebih tinggi dibandingkan kalangan lakilaki. Berdasarkan hasil data responden pada penelitian ini, tingkat motivasi berhenti merokok lebih tinggi pada kalangan perempuan dibandingkan dengan kalangan lakilaki. Motivasi instrinsik memiliki peranan yang lebih besar terhadap tindakan seseorang, tindakan tersebut dapat dilakukan tanpa adanya pengaruh dari lingkungan sekitar, berdasarkan hasil data responden pada penelitian ini pengaruh faktor instrinsik terhadap motivasi berhenti merokok lebih besar dibandingkan dengan faktor ekstrinsik.

\section{Kesimpulan}

Berdasarkan hasil penelitian yang telah dilakukan dapat disimpulkan bahwa: Terdapat hubungan yang signifikan antara tingkat pengetahuan tentang dampak rokok terhadap kesehatan rongga mulut dengan tingkat motivasi berhenti merokok pada mahasiswa Universitas Kristen Maranatha.

\section{Referensi}

1. Aditama, T. Y. Proses Berhenti Merokok. Jurnal Cermin Dunia Kedokteran 1995. 102: 37- 9.

2. BPdPKK. Riset Dasar Kesehatan Tahun. Jakarta; Kesehatan Kementrian Republik Indonesia; 2010: p. 329-334.

3. Ambarwati., Ayu, K. U., Kurniawati, F., Tika, D. K., Saroh, D. Media Leaflet, Video dan Pengetahuan Siswa SD Tentang Bahaya Merokok. Surakarta: Universitas Muhamadiyah Surakarta. 2014.

4. Maspupah, R. Kebiasaan Merokok di Kalangan Mahasiswa (Studi Pada Mahasiswa Fakultas Ilmu Sosial dan Ilmu Politik Universitas Riau). Riau: Universitas Riau. 2013. 
5. Henni, B. Hubungan Pengetahuan Perokok Aktif Tentang Rokok dengan Motivasi Berhenti Merokok Pada Mahasiswa FKM dan FISIP Universitas Indonesia. Jakarta: Universitas Indonesia. 2015.

6. Lauren. In Defense Of Smokers. Indonesia Berdikari: Jakarta Selatan. 2014.

7. Song et.al. Perceptions of Smoking-Related Risks and Benefits as Predictors of Adolescent Smoking Initation. American Journal of Public Health, volume 99, No.3, March 2009.

8. GATS. Global Adults Tobacco Survei Indonesia Report. New Delhi:WHO Regional Office For South-East Asia. 2011.

9. Williams, R. J., Herzogb, T. A., \& Simmonsc, V. N. Risk Perception and motivation to quit smoking: A partial test of the Health Action Process Approach. Addict Behaviour 36(7), 789-791. 2011.

10. Ayu, Z. W. Tingkat Ketergantungan Merokok dan Motivasi Berhenti Merokok pada Pegawai FKG USU dan Supir Angkot Medan. Sumatra Utara: Universitas Sumatra Utara. 2014.

11. Notoatmodjo, S. Promosi Kesehatan Teori dan Aplikasi. Jakarta: PT Rineka Cipta. 2005 .

12. Koeswara. Motivasi: Teori dan Penelitiannya. Bandung: Angkasa. 1989.

13. Notoatmodjo, S. Promosi Kesehatan dan Ilmu Perilaku. Jakarta : Rineka Cipta. 2007.

14. Dwi, O. Hubungan Persepsi, Dukungan Sosial, dan Status Sosial Ekonomi dengan Motivasi Mahasiswa Untuk Melanjutkan Profesi Ners di Universitas Muhammadiyah Purwokerto. Purwokerto: Universitas Muhammadiyah. 2015.

15. Purwanto, M. N. Psikologi Pendidikan. Bandung: Remaja Rosdakarya. 2007.

16. Hamzah, B. U. Teori Motivasi dan Pengukurannya Analisis di Bidang Pendidikan. Jakarta: Bumi Aksara. 2008.

17. Asmuji. Manajemen Keperawatan : Konsep dan Aplikasi. Yogyakarta: Ar-Ruzz Media. 2012.

18. Notoatmodjo, S. Ilmu Perilaku Kesehatan. Jakarta: Rineka Cipta. 2010.

19. Suhardi. The Science of Motivation (Kitab Motivasi). Jakarta : PT Gramedia. 2013.

20. Taufik. Psikologi Komunikasi. PT. Remaja Rosdakarya: Bandung. 2007.

21. Pradana, K. A. Dinamika Motivasi Mengakhiri Perilaku Merokok Pada Mantan Perokok Yang Pernah Mengalami Fase Relapse (Skripsi) . Jakarta: Universitas Indonesia. 2008.

22. Hernowo. Panduan Untuk Perokok. Jakarta : EGC. 2007.

23. Gondodiputro., Sharon. Bahaya Tembakau dan Bentuk-Bentuk Sediaan Tembakau. Bandung: Fakultas Kedokteran Universitas Padjadjaran. 2007.

24. Arief, S. Radikal Bebas. Ilmu Kesehatan Anak. Surabaya : FK UNAIR. 2007.

25. Triswanto., Sugeng, D. Stop Smoking. Yogyakarta: Progresif Books :15-119. 2007.

26. Bare, B. G., Smeltzer, S. C. Buku Ajar Keperawatan Medikal Bedah. Jakarta: EGC. 2001. 
27. Djauzi, S. Raih Kembali Kesehatan. Jakarta: Kompas. 2009.

28. Tandra. Merokok dan Kesehatan. Surabaya : Berita KOMNAS PMM http://www.antirokok.or.id. . 2003

29. Dewi, D. Pengaruh kebiasaan merokok terhadap mukosa mulut. Dentika Dental Journal, vol.10, no 2, hlm 132-5. 2005.

30. Setiadhi R., Soewondo, W. Hubungan Antara Pigmentasi Melanin pada Gingiva Anak- anak dengan Riwayat Orangtua Perokok di Rumah Sakit Gigi dan Mulut Fakultas Kedokteran Gigi Universitas Padjadjaran. Bandung: Universitas Padjadjaran. 2011.

31. Krisna, I. P. Perbedaan PH Saliva Pada Perokok Putih dan Perokok Kretek Sesaat Setelah Merokok. Denpasar: Universitas Mahasaraswati. 2014.

32. Nursalam., Efendi, F. Pendidikan Dalam Keperawatan. Jakarta : Salemba Medika. 2008.

33. Aditama, T.Y. 2002. Rokok dan Kesehatan. Jakarta: Universitas Indonesia.

34. WHO. About Cardiovascular diseases. World Health Organization. Geneva. Cited July 15th $2014 . \quad$ Available from URL

: http://www.who.int/cardiovascular_diseases/about_cvd/en/accessed on. 2013.

35. Syafiie, R. Stop Smoking ! Studi Kualitatif Terhadap Pengalaman Mantan Pecandu Rokok dalam Menghentikan Kebiasaannya. (Thesis). Semarang: Universitas Diponegoro. 2009.

36. Lousia, M., Sadikin, Z. D. Program Berhenti merokok. Majalah Kedokteran Indonesia. Hal. 131-137. 2008.

37. Sabri, Y. S. Berhenti Merokok. Padang: Perhimpunan Dokter Paru Indonesia. 2011.

38. Santrock, J. W. Perkembangan Remaja. Jakarta: Erlangga. 2003.

39. Gunarsa, S. D. Bunga rampai psikologi perkembangan dari anak sampai usia lanjut. Jakarta

: BPK. 2004.

40. Widyastuti, Y., Rahmawati, A., Purnamaningrum, Y. E. Kesehatan Reproduksi, Yogyakarta:Fitramaya. 2009.

41. Hurlock B. E. Perkembangan Anak. Jilid 1. Penerbit Erlangga. Jakarta. 2006.

42. Santrock, J. W. Life-Span Development: Perkembangan Masa Hidup (edisi kelima). (Penerj. Achmad Chusairi, Juda Damanik; Ed. Herman Sinaga, Yati Sumiharti). Jakarta: Erlangga. 2002.

43. Lemeshow, S., et al. Adequacy Of Sample Size in Health Studies. Diterjemahkan Oleh Dibyo Pramono dengan Judul Besar Sampel dalam Penelitian Kesehatan. 1997. Yogyakarta: Gajah Mada University Press. 1990.

44. Sugiyono. Metode Penelitian Pendidikan (Pendekatan Kuantitatif, dan R\&D). Penerbit CV. Alfabeta: Bandung. 2015.

45. Hadi, S. Statistik 2. Yogyakarta: Andi Offset. 2007.

46. Notoatmodjo, S. Pendidikan Dan Perilaku Kesehatan. Jakarta: Rineka Cipta. 2003.

47. Putri, S. A. Motivasi untuk Berhenti Merokok pada Mahasiswa Perokok Berat 
ditinjau dari Self Efficacy dan Pengetahuan Bahaya Rokok. Semarang: Universitas Katolik Soegijapranata. 2015.

48. Warnakulasuriya, S., Dietrich, T., Bornstein, M., Peidró, E., Preshaw, P., Walter, C., Wennström, J., Bergström, J. Oral health risks of tobacco use and effects of cessation. International Dental Journal 2010. 60:7-30.

49. Dewi, N. M., Wahyadi, D., Hayatun, S., Irene, S. The Effect of Daily Lifestyle on Periodontal Health. Jakarta: Universitas Indonesia. 2005.

50. Sham, A., Cheung, L., Jin, L., Corbet, E. The effects of tobacco use on oral health. Hong Kong Med J 2003. 9 : 271-7.

51. Wulandari, A., Julia, R., Reginus, M. Hubungan Merokok Dengan Kesehatan Gigi dan Mulut Pada Pria Dewasa di Desa Poyowa Kecil Kecamatan Kotamobagu Selatan Kota Kotamobagu. Universitas Sam Ratulangi:Kotamobagu. 2016.

52. Debora L. T. Tembakau dan Pengaruhnya Terhadap Kesehatan Mulut. Jakarta: Universitas Kristen Krida Wacana. 2011.

53. Carranza, F. A., Newman, M.G. Clinical Periodontology. London: WB Saunders Company. 2006.

54. Indrayadi, G., Yuniardini, S. W. Oral Probiotik: Pendekatan Baru Terapi Halitosis. Jakarta: Universitas Indonesia. 2009.

55. Asma, A., Zulkifli, A., Thaha, I. L. Analisis Motivasi Berhenti Merokok Laki-Laki Dewasa Awal di Pesisir Puskesmas Pundata Baji. Makassar: Universitas Hasanuddin. 2015.

56. Ali, M. Pengetahuan, Sikap, Dan Faktor Psikologis Berhubungan dengan Perilaku Merokok Pada Pegawai Poltekkes Kemenkes Jakarta III. Jurnal Ilmu Teknologi Kesehatan Vol.2 Nomor 1, 101-107. 2014.

57. Agus, A., Nopianto. Determinan Perilaku Merokok Pada Remaja. Pekanbaru: STIKes Hang Tuah Pekanbaru. 2017.

58. Rahmadi, A., Yuniar, L., Yenita. Hubungan Pengetahuan dan Sikap Terhadap Rokok dengan Kebiasaan Merokok Siswa SMP di Kota Padang. Padang: Universitas Andalas. 2013.

59. Widiansyah, M. Faktor-faktor Penyebab Perilaku Remaja Perokok di Desa Sidorejo Kabupaten Penajam Paser Utara. Samarinda: Universitas Mulawarman. 2014.

60. Dwi, K. Faktor Psikologis yang Mempengaruhi Perilaku Merokok pada Remaja. Jakarta: Universitas Bina Nusantara. 2012.

61. Hikmah, N. Hubungan Lama Merokok dengan Derajat Hipertensi di Desa Rannaloe Kecamatan Bungaya Kabupaten Gowa. Makassar: Universitas Islam Negeri Alauddin. 2017.

62. Gusnida. Hubungan Perbedaan Usia Pekerjaan dan Lama Merokok dengan Tanggapan Terhadap Gambar Peringatan Bahaya Merokok Pada Kemasan Rokok. Padang: Universitas Andalas. 2016. 